A SB 1999 Conference

Halifax, Nova Scotia
Sean Cleary

Frank H. Sobey Faculty of Commerce

Saint $M$ ary's U niversity

\title{
THE SENSITIVITY OF CANADIAN CORPORATE INVESTMENT TO LIQUIDITY ${ }^{1}$
}

This study confirms that liquidity is a significant determinant of Canadian corporate investment. Contrary to recent U.S. evidence, the investment-liquidity sensitivity of financially constrained firms is not found to be significantly different from that of unconstrained firms. This is attributed to the industry structure and closely held nature of Canadian firms.

\section{Introduction}

Fazzari, Hubbard and Petersen (1988) and a number of subsequent empirical studies provide strong support for the existence of a direct relationship between internal fund availability and firm investment ${ }^{2}$. The majority of these studies have found the investment decisions of firms that are more financially constrained to be more sensitive to firm liquidity than those of less constrained firms. Recent studies by Kaplan and Zingales (1997), and Cleary (1999) examine firm level data for U.S. companies and find that the investment decisions of firms with greater creditworthiness according to traditional financial ratios are the most sensitive to the availability of internal cash flows. This seems to contradict previous results, if we accept firm financial status as a measure of financial constraint.

This study examines the investment behavior of 201 Canadian firms over the 1988-94 period. The results confirm the sensitivity of investment decisions to firm liquidity for Canadian firms over this sample period, which is consistent with previous empirical studies, and extends the Canadian evidence provided by Schaller (1993), who examined 212 Canadian firms over the 1973-86 period. Results suggest that partially constrained and financially constrained firms are more sensitive to liquidity than unconstrained firms. This does not support the conclusions of K aplan and Zingales (hereafter K Z) or Cleary (1999), who both used U.S. samples. The difference from U.S. results is attributed to the industry structure and closely held nature of Canadian firms, although the Canadian evidence is inconclusive. In particular, regression results demonstrate the behavior of a relatively small number of firms in a sample can have a significant impact on overall conclusions, which highlights the importance of obtaining large sample

\footnotetext{
${ }^{1}$ I am grateful to Laurence B ooth, G lenn Hubbard, D onald B rean, V arouj Aivazian and Raymond $\mathrm{K}$ an for their general comments. I am also especially grateful to an anonymous reviewer at the Canadian J ournal of A dministrative Sciences whose comments lead to substantial improvements All errors are the responsibility of the author.

${ }^{2}$ There are numerous other examples including studies by Hoshi, K ashyap and Scharfstein (1991) and W hited (1992). For an extensive review of this literature, refer to Hubbard (1998).
} 
evidence. This is an important observation, since the conclusions of several previous studies are based on small sample results ${ }^{3}$.

\section{Data and M ethodology}

The sample includes annual data for 201 Canadian corporations over the 1988-94 period obtained from the SEC Disclosure W orldscope Database. The sample contains both manufacturing and non-manufacturing companies from a variety of industries including: 52 agricultural, mining, resource and forestry companies; 98 industrial manufacturing companies; 37 retail and wholesale companies; and 14 service companies. Summary statistics for the entire sample are found in Table 1.

This study focuses on financial status, as measured by financial statement variables, using the classification scheme of Cleary (1999). The index used to classify firm financial status is determined using multiple discriminant analysis, similar to A Itman's Z factor for predicting bankruptcy ${ }^{4}$. Discriminant analysis examines an entire profile of characteristics common to a group of firms, as well as the interaction of these properties, and transforms them into a univariate statistic. This allows the analysis of the entire variable profile of a firm simultaneously, rather than sequentially examining the individual characteristics.

In order to use discriminant analysis to determine financial constraint status, I establish two mutually exclusive groups by making use of knowledge that firms do not like to cut dividends and are hesitant to increase them unless they can be maintained. A ccordingly, the sample is divided into three categories: group 1 firms that increase dividends and are likely not financially constrained; group 2 firms that cut dividends and are likely financially constrained; and group 3 firms that do not change dividend payments. G roup 3 firms are not utilized for purposes of the discriminant analysis, how ever, they are assigned discriminant (Z) scores and are used in the subsequent regression analysis. This group of firms represents a significant proportion of the sample ( 58 percent), and they can be categorized by reference to their discriminant score as those that 'fit the profile' of constrained or unconstrained firms, which enables the use of an increased sample size.

Summary statistics reported in Table 1 confirm that firms reducing dividends appear to be more financially constrained according to traditional financial ratios. Firms that cut dividends exhibit lower current ratios, higher debt ratios, lower fixed charge coverage, lower net income margins, lower market-to-book ratios, lower sales growth, and have lower SL A CK/K values than firms which increased dividends. The standard ratio performance for firms that did not increase or decrease dividend payments, was between the other two groups. Panel B of Table 1 indicates substantial changes in the number of firms that increase and decrease dividends through the years. The largest number of firms increasing dividends (89) occurred in the pre-recessionary year of 1988, while the largest number of firms cutting dividends (60) occurred in 1991. This confirms that firm financial status changes in response to business cycles, and suggests there are benefits associated with reclassifying firm status every period.

${ }^{3}$ For example, Fazzari, Hubbard and Petersen (1988) have only 49 firms in one group and only 39 in another. K aplan and Zingales (1997) use three groups of 19, 22 and 8 firms, while H oshi, K ashyap and Scharfstein (1991) have only 24 firms in their group of constrained firms.

${ }^{4}$ Refer to Altman (1968). 
Table 1

Summary Statistics (1988-94)

Panel A - Selected F inancial R atio M eans (1988-94)

\begin{tabular}{|c|c|c|c|c|}
\hline & Total Sample & $\begin{array}{l}\text { Dividend G roup } 1 \\
\text { (increased dividend } \\
\text { per share) }\end{array}$ & $\begin{array}{l}\text { Dividend G roup } 2 \\
\text { (decreased dividend } \\
\text { per share) }\end{array}$ & $\begin{array}{l}\text { Dividend G roup } 3 \\
\text { (no change in } \\
\text { dividend per share) }\end{array}$ \\
\hline $\begin{array}{l}\text { Net Fixed } \\
\text { A ssets (K) }\end{array}$ & $\$ 762 m$ & $\$ 820 \mathrm{~m}$ & $\$ 1012$ & $\$ 668 \mathrm{~m}$ \\
\hline Current Ratio & 2.23 & 2.24 & 1.88 & 2.32 \\
\hline $\begin{array}{l}\text { D ebt/Total } \\
\text { A ssets }\end{array}$ & 0.27 & 0.23 & 0.30 & 0.28 \\
\hline $\begin{array}{l}\text { Fixed Charge } \\
\text { Coverage }\end{array}$ & 9.8 & 11.8 & 6.5 & 9.8 \\
\hline $\begin{array}{l}N \text { et Income } \\
M \text { argin (\%) }\end{array}$ & 3.5 & 7.0 & 0.8 & 2.6 \\
\hline $\begin{array}{l}\text { M arket-to- } \\
\text { B ook Ratio }\end{array}$ & 1.35 & 1.50 & 1.18 & 1.33 \\
\hline $\begin{array}{l}\text { Sales G rowth } \\
(\%)\end{array}$ & 12.8 & 15.9 & 4.7 & 13.5 \\
\hline Slack/K & 0.76 & 1.01 & 0.84 & 0.63 \\
\hline $\begin{array}{l}\text { (Cash Flow } \\
+ \text { Cash)/K }\end{array}$ & 0.32 & 0.49 & 0.19 & 0.27 \\
\hline Investment/K & 0.20 & 0.23 & 0.16 & 0.20 \\
\hline $\begin{array}{l}\text { Discriminant } \\
\text { Score }(Z)\end{array}$ & -0.02 & 0.25 & -0.42 & -0.17 \\
\hline
\end{tabular}

\begin{tabular}{llllllllll}
\multicolumn{10}{c}{ Panel B - Number of Firms per Dividend Group } \\
Dividend G roup & $\mathbf{1 9 8 8 - 9 4}$ & $\underline{\mathbf{1 9 8 8}}$ & $\underline{\mathbf{1 9 8 9}}$ & $\underline{\mathbf{1 9 9 0}}$ & $\underline{\mathbf{1 9 9 1}}$ & $\underline{\mathbf{1 9 9 2}}$ & $\underline{\mathbf{1 9 9 3}}$ & $\underline{\mathbf{1 9 9 4}}$ \\
\hline $\mathbf{1}$ (increased DPS) & $\mathbf{3 7 6}$ & $\mathbf{8 9}$ & $\mathbf{7 9}$ & $\mathbf{5 1}$ & $\mathbf{3 1}$ & $\mathbf{4 2}$ & $\mathbf{5 1}$ \\
& $(26.7 \%)$ & $(44.3 \%)$ & $(39.3 \%)$ & $(27.4 \%)$ & $(15.4 \%)$ & $(20.9 \%)$ & $(14.4 \%)$ & $(25.4 \%)$ \\
$\mathbf{2}$ (decreased DPS) & 218 & 19 & 20 & 37 & 60 & 40 & 28 & 14 \\
& $(15.5 \%)$ & $(9.5 \%)$ & $(10.0 \%)$ & $(18.4 \%)$ & $(29.9 \%)$ & $(19.9 \%)$ & $(13.9 \%)$ & $(7.0 \%)$ \\
$\mathbf{3}$ (no change in DPS) & 813 & 93 & 102 & 109 & 110 & 119 & 144 & 136 \\
& $(57.8 \%)$ & $(46.3 \%)$ & $(50.8 \%)$ & $(54.2 \%)$ & $(54.7 \%)$ & $(59.2 \%)$ & $(71.6 \%)$ & $(67.7 \%)$
\end{tabular}

The following beginning of period variables are used to estimate the discriminant function: current ratio, debt ratio, fixed charge coverage (FCCov), net income margin ( $\mathrm{N} / \%$ ), sales growth, and SLACK/K. Coefficient values are estimated for the independent variable in order to distinguish between the two groups according to the following $Z_{F C}$ value:

$$
\mathrm{Z}_{\mathrm{FC}}=\beta_{1} \text { Current }+\beta_{2} \mathrm{FCCOV}+\beta_{3} \mathrm{SLACK} / \mathrm{K}+\beta_{4} \mathrm{NI} \%+\beta_{5} \text { SalesGrowth }+\beta_{6} \text { Debt. }
$$

U nivariate significance levels indicate net income margin, sales growth, and debt ratio are all significant at the one percent significance level, while current ratio and fixed charge coverage are significant at the 13 percent and 11 percent levels. The variables do a good job of successfully predicting which firms will cut or increase dividends, with group 1 and group 2 firms being properly classified 64 percent of the time, how ever this success rate is well below the 76 percent rate documented by Cleary (1999). There are several reasons that likely account for this 
difference, the most obvious being the much smaller sample size used in the present study. A nother reason is the different nature of the samples. In particular, the Canadian sample is much more heterogeneous than the U.S. one, consisting of only 48 percent manufacturing companies versus 64 percent in the U.S. sample, and 26 percent resource-based companies versus a mere 7.5 percent in the U.S. sample ${ }^{5}$.

\section{Table 2}

\section{Selected Financial R atio M eans (1988-94)}

All financial variables are for the beginning of the fiscal year, except for cash flow and investment, which represent firm cash flow and capital expenditures during period ' $t$ '.

\begin{tabular}{|c|c|c|c|c|c|}
\hline & $\begin{array}{l}\text { FC100 firms } \\
\text { (financially } \\
\text { constrained) }\end{array}$ & $\begin{array}{l}\text { NFC100 firms } \\
\text { (not } \\
\text { financially } \\
\text { constrained) }\end{array}$ & $\begin{array}{l}\text { FC67 firms } \\
\text { (financially } \\
\text { constrained) }\end{array}$ & $\begin{array}{l}\text { PFC67 firms } \\
\text { (partially } \\
\text { financially } \\
\text { constrained) }\end{array}$ & $\begin{array}{l}\text { NFC67 firms } \\
\text { (not } \\
\text { financially } \\
\text { constrained) }\end{array}$ \\
\hline $\begin{array}{l}\text { Net Fixed Assets } \\
\text { (K) }\end{array}$ & $\$ 729 m$ & $\$ 797 m$ & $\$ 626 m$ & $\$ 1000 \mathrm{~m}$ & $\$ 659 m$ \\
\hline Current Ratio & 1.78 & 2.67 & 1.77 & 1.86 & 3.07 \\
\hline Debt/Total A ssets & 0.38 & 0.17 & 0.42 & 0.26 & 0.14 \\
\hline $\begin{array}{l}\text { Fixed Charge } \\
\text { Coverage }\end{array}$ & 7.0 & 12.8 & 6.5 & 8.1 & 15.0 \\
\hline $\begin{array}{l}\text { Net Income } M \text { argin } \\
(\%)\end{array}$ & -2.5 & 9.3 & -5.1 & 3.7 & 11.8 \\
\hline $\begin{array}{l}\text { M arket-to-B ook } \\
\text { Ratio }\end{array}$ & 1.17 & 1.53 & 1.15 & 1.24 & 1.67 \\
\hline $\begin{array}{l}\text { Sales Growth } \\
(\%)\end{array}$ & 2.8 & 22.7 & 0.8 & 6.8 & 30.7 \\
\hline Slack/K & 0.70 & 0.82 & 0.69 & 0.73 & 0.86 \\
\hline $\begin{array}{l}\text { (Cash } \\
\text { Flow+Cash)/K }\end{array}$ & 0.23 & 0.36 & 0.20 & 0.31 & 0.44 \\
\hline Investment / K & 0.16 & 0.24 & 0.15 & 0.20 & 0.26 \\
\hline $\begin{array}{l}\text { Discriminant } \\
\text { Score }(Z)\end{array}$ & -0.89 & 0.68 & -1.20 & -0.10 & 1.00 \\
\hline
\end{tabular}

Discriminant analysis differentiates best between firms when they are homogeneous in nature with respect to variables other than those being examined, and therefore it is logical that it would perform better for more homogeneous samples. This implies that better results would be obtained by performing discriminant analysis on firms within industry categories, and that turns out to be the case. When the sample is divided into three industry groups according to their $\mathrm{SIC}$ codes, the overall success rates in predicting which firms will change their dividends increase substantially. In particular, the following success rates are achieved for the industry groups: 67 percent for the group of 52 resource-based firms; 73 percent for the group of 98 manufacturing

\footnotetext{
${ }^{5}$ It may al so be partially attributable to differences in dividend behavior between Canadian and U.S. managers, although this hypothesis is not explored in this study.
} 
firms; and 71 percent for the group of 51 firms categorized as retail and wholesale firms, or service firms.

Firms are allocated to groups every year, according to their discriminant score $\left(Z_{F C}\right)^{6}$. This allows firm classification to change every period to reflect the fact that financial status changes continuously. E very year, the 100 firms with the highest Z scores are assigned to the not financially constrained (NFC100) group, while the ones with the 100 lowest values are assigned to the financially constrained (FC100) group. In order to account for any significant differences in the financial constraint status of firms ranked close to the median, this procedure is repeated to form three groups instead of two. Each year, I assign firms with the top 67 discriminant scores to the not financially constrained (NFC67) group, firms with the bottom 67 discriminant scores to the financially constrained (FC67) group, and the remaining firms to the partially constrained (PFC67) group. Table 2 displays summary statistics for these groups that confirm the effectiveness of this approach in capturing desired cross-sectional properties. The financial status of the NFC100 firms is far superior to that of the FC100 group, while the NFC67 firms are superior to the PFC67 firms, and the FC 67 firms appear more constrained than both the PFC67 and NFC67 firms.

I use a variation of the basic regression equation used by most previous studies including FHP88 and KZ to examine investment-liquidity sensitivity:

$$
(\mathrm{I} / \mathrm{K})_{\mathrm{it}}=\alpha_{\mathrm{it}}+\beta_{\mathrm{M} / \mathrm{B}}(\mathrm{M} / \mathrm{B})_{\mathrm{it}}+\beta_{\mathrm{CF} / \mathrm{K}}((\mathrm{CF}+\mathrm{Cash}) / \mathrm{K})_{\mathrm{it}}+\varepsilon_{\mathrm{it}} .
$$

I represents investment in plant and equipment during period $t, K$ is the beginning of period book value for net property, plant, and equipment, ( $C F+C$ ash) represents current period cash flow to the firm (as measured by net income plus depreciation plus the change in deferred taxes) plus the beginning-of-period balances of cash plus short-term securities; and M /B represents the firm's market-to-book ratio for total assets, based on the previous year's market value at year end.

The market-to-book to ratio is used to proxy for growth opportunities, while $(C F+C$ ash $) / K$ is used to proxy for firm liquidity. The equation is estimated using fixed effects to account for unobserved relationships between investment and the independent variables, and to capture business-cycle influences, which is consistent with previous studies. Results are reported for the 'demeaned' or 'within' fixed firm and year estimates, which coincides with estimates presented by FHP88 and $\mathrm{KZ}$.

Empirical $p$-values are determined using the bootstrap methodology described in Cleary (1999) in order to determine the significance levels of observed differences in coefficient estimates. The regression results highlight the benefit of calculating empirical values, since some rather large differences in coefficient estimates are found to be insignificant, contrary to what might have been expected.

\footnotetext{
${ }^{6}$ I use the discriminant scores obtained using the entire sample (despite the lower success rate), not those obtained within industry groups. This is because the values determined within industry groups are relative scores within that group, which are not directly comparable with values for firms in different industry groups.
} 


\section{Results}

Regression results presented in Table 3 indicate that liquidity and market-to-book are both significant determinants of investment (at the one percent level) for the entire sample of 201 firms, with estimated coefficients of 0.098 and 0.028 respectively. These values differ somewhat from those of Schaller (1993), who obtained fixed effects estimates of 0.242 and 0.007 for CF/K and Tobin's q. This may be attributable to the different time periods being examined, as well as the use of different proxies for growth opportunities and liquidity. The estimates are much closer to the estimates of 0.043 for Tobin's $q$ and 0.058 for CF/K that are obtained by Cummins, Hassett and Hubbard (1996) for the Canadian firms they examine over the 1982-1992 period.

Table 3 presents regression evidence for the two groups (NFC100 and FC100) that are formed by dividing the sample in half according to the classification scheme described in the previous section. The estimated liquidity coefficient is positive and significant for both groups, however, it is almost four times as large for the financially constrained group ( 0.197 versus 0.050). This evidence appears to support the conclusions of previous studies that investment is more closely related to liquidity for firms facing greater levels of financial constraints. However, the empirical $p$-value of 0.0666 suggests the difference in coefficient estimates is only significant at the 6.66 percent level, which is not as conclusive as one might expect, given the magnitude of the difference.

One would expect to observe even greater differences in liquidity coefficient estimates between the unconstrained and constrained groups (NFC67 and FC67) when the sample is divided into three groups, since this classification approach places greater emphasis on firms ranked at either extreme of the sample. The results for the NFC67 group are virtually identical to those for the NFC100 group, however, the estimates for the FC67 group change quite dramatically from those for the FC100 group. The liquidity coefficient for the FC 67 group falls to 0.100 from 0.197 . The empirical $p$-value suggests the difference in liquidity coefficient estimates between the NFC67 and FC67 groups is only significant at the 27 percent level.

The reason for this surprising turn of events becomes obvious when we examine the results for the PFC67 group. The estimated liquidity coefficient for this group is 0.267 , which is 2.67 times the FC67 group estimate and more than five times the NFC 67 group estimate. A pparently, the results for the $\mathrm{FC} 100$ group are driven to a large extent by observations for some firms ranked between 100 and 133 according to their discriminant scores. Under the alternative grouping mechanism, these firms are classified in the PFC67 group and produce some unanticipated results. The empirical $p$-value indicates the observed difference in liquidity coefficient estimates between the PFC 67 group and the NFC67 group is significant at the 3.90 percent level. However, despite a relatively large difference in liquidity coefficient estimates between the PFC67 and FC67 groups, the difference is insignificant.

The results demonstrate the importance of having an adequate number of firms in a group for comparison purposes, since the behavior of a few firms can have a significant effect on overall conclusions. They also demonstrate the usefulness of determining empirical $p$-values, because we observe some rather large differences in coefficient estimates to be insignificant, contrary to what one might expect. These observations withstand a number of robustness tests including al ternative regression estimation techniques, and the elimination of extreme observations, although the results of these tests are not reported here in the interest of brevity. 


\section{Table 3}

\section{Regression Estimates for the T otal Sample}

Reported coefficients are the 'within' fixed firm and year estimates over the 1988-94 sample period. Tstatistics are in parentheses. Capital expenditures divided by net fixed assets is the dependent variable. Pvalues in bold indicate a significant difference in coefficient estimates at the $5 \%$ level.

\begin{tabular}{lcccc}
\hline & M arket-to-B ook & $\begin{array}{c}\text { (CF+Cash)/Net } \\
\text { Fixed A ssets }\end{array}$ & $\begin{array}{c}\text { A djusted } \\
\text { R-squared }\end{array}$ & $\begin{array}{c}\text { N umber of } \\
\text { Observations }\end{array}$ \\
\hline Regression E stimates & & & & \\
Total Sample & $0.028(2.86)$ & $0.098(9.82)$ & $6.93 \%$ & 1407 \\
FC100 firms & $0.053(2.88)$ & $0.197(11.80)$ & $17.65 \%$ & 700 \\
NFC100 firms & $0.014(1.17)$ & $0.050(4.10)$ & $2.29 \%$ & 700 \\
FC67 firms & $0.056(3.86)$ & $0.100(6.84)$ & $11.32 \%$ & 469 \\
PFC67 firms & $0.055(1.88)$ & $0.267(9.90)$ & $18.40 \%$ & 469 \\
NFC67 firms & $0.005(0.34)$ & $0.052(3.77)$ & $2.58 \%$ & \\
E mpirical P-values & & & & \\
FC100 versus & 0.2280 & 0.0666 & & \\
NFC100 & 0.4890 & 0.7890 & & \\
FC67 versus PFC67 & 0.1680 & 0.2672 & \\
FC67 versus NFC67 & 0.1886 & $\mathbf{0 . 0 3 9 0}$ & \\
PFC67 versus NFC & & & \\
\hline
\end{tabular}

A s mentioned previously, there are substantial differences in the nature of the sample used in this study and those used in many previous studies that are primarily due to the distinct nature of the Canadian economy. I now examine if sample differences account for the differences in my results from those of previous studies, with particular emphasis on the Cleary (1999) results, which were obtained using the same methodology. A side from sample size, two of the most important sample differences are industry structure and ownership structure. In particular, Canada relies more heavily on resource based industries than many other developed economies, and Canadian firms tend to be much more closely held than their U.S. counterparts.

O wnership groups were formed according to ownership structure based on the largest percentage of the firm's common shares owned by any given shareholder as of December 31, 1991 (the mid-way point of the sample horizon). O wnership Group A (Own A) consists of firms with no single shareholder owning more than 20 percent of the firm's outstanding shares and can be considered widely held. Ownership Group B (Own B) consists of firms where the largest single shareholder owns between 20 and 50 percent of the firm's shares. Ownership Group $C$ (own C) consists of firms where the largest single shareholder owns more than 50 percent of the firm's shares. 
I was able to find ownership data for 196 of 201 firms in total, and the sample was found to consist of 42 (21 percent) Own A firms, 72 Own B firms ( 36 percent), and 82 (41 percent) Own $\mathrm{C}$ firms. This implies that only about 1 in 5 firms was widely held. While comparable statistics are not available from previous U.S. studies, it is reasonable to assume they would consist of a much higher proportion of widely held firms since most of the samples consisted entirely or to a large extent of NY SE-listed firms, which tend to be widely held.

Regression results are presented for these ownership groups in Table 4, which suggest that widely held firms ( $O w n A$ ) are more sensitive to liquidity than both other groups. The liquidity coefficient for the 0 wn $A$ group of 0.238 is almost four times as large as the coefficient for the Own C group (0.060), and the difference is significant at the 4.26 percent level. However, despite being almost three times as large as the 0 wn $B$ group coefficient of 0.084 , the difference is only significant at the 17 percent level. These observations conform to expectations, since they are consistent with the existence of a smaller wedge between the cost of internal and external finance due to lower informational asymmetry problems that would be attributed to more closely held firms. As a result, we would expect these firms to be less sensitive to internal fund availability than widely held firms. The results also support those of Schaller (1993) who found that firms with wider ownership concentration $(<50 \%)$ were more than twice as sensitive to liquidity (with a cash flow coefficient of 0.366 ) than those with concentrated ownership (0.154).

Firms are also categorized into three industry groups according to their SIC codes as described previously, and the regression results for these groups are presented in Table 4. A priori, one would expect resource firms to be less sensitive to liquidity and market-to-book ratios than other firms, with investment decisions being driven by factors such as successful exploration ventures and/or commodity prices. This was found to be the case, as demonstrated in Table 6 , where we observe an insignificant coefficient for market-to-book, and a relatively small liquidity coefficient of 0.037 , al though it is significant. The liquidity coefficients for the other two industry groups are much higher: manufacturing firm group (0.163); and retail/wholesale and retailing firm group (0.146). The difference between the liquidity coefficients of the resource and manufacturing firms is significant at the 2.62 percent level. How ever, despite the fact that the liquidity coefficient retail/wholesale and service group is al most four times that of that for the resource group, the difference is only significant at the 15.26 percent level. Once again the overall results are consistent with the results of Schaller (1993), who found that manufacturing firms had much higher liquidity coefficients than non-manufacturing firms $(0.597$ versus 0.168$)$, al though he does not further refine his sample to identify resource based firms.

In summary, it appears quite likely that the distinct characteristics of the present sample contribute to the unique results. In particular, resource and closely held firms are less sensitive to liquidity than manufacturing and widely held firms, and this sample contains a higher proportion of such firms than was true of previous U.S. studies ${ }^{7}$.

\footnotetext{
${ }^{7}$ I also considered the impact on the overall results of applying the classification approach described above to a given industry group. The emerging patterns within these groups supported the overall results for the manufacturing group, and to a lesser extent for the retail/wholesale and service group, while they are inconclusive for the resource group.
} 


\section{TABLE 4}

\section{Regression E stimates for $\mathbf{O}$ wnership and Industry G roups}

Reported coefficients are the 'within' fixed firm and year estimates over the 1988-94 sample period. T-statistics are in parentheses. Capital expenditures divided by net fixed assets is the dependent variable. P-values in bold indicate a significant difference in coefficient estimates at the $5 \%$ level.

\begin{tabular}{|c|c|c|c|c|}
\hline & M arket-to-B ook & $\begin{array}{c}(\mathrm{CF}+\mathrm{C} \text { ash }) / \mathrm{N} \text { et } \\
\text { Fixed A ssets }\end{array}$ & $\begin{array}{l}\text { A djusted } \\
\text { R-squared }\end{array}$ & $\begin{array}{l}\text { Number of } \\
\text { Observations }\end{array}$ \\
\hline \multicolumn{5}{|l|}{ Regression E stimates } \\
\hline $\begin{array}{l}\text { Ownership Group } A \\
\text { (Own A) }\end{array}$ & $0.095(6.49)$ & $0.238(6.81)$ & $26.44 \%$ & 294 \\
\hline $\begin{array}{l}\text { Ownership Group B } \\
(O w n B)\end{array}$ & $-0.008(-0.51)$ & $0.084(4.97)$ & $4.42 \%$ & 504 \\
\hline $\begin{array}{l}\text { Ownership Group C } \\
\text { (Own C) }\end{array}$ & $0.083(4.57)$ & $0.060(4.23)$ & $6.84 \%$ & 574 \\
\hline $\begin{array}{l}\text { SIC 1-1999- } \\
\text { Resource Firms } \\
\text { (SIC1) }\end{array}$ & $0.009(0.60)$ & $0.037(2.44)$ & $1.13 \%$ & 364 \\
\hline $\begin{array}{l}\text { SIC 2000-3999- } \\
\text { M anufacturing Firms } \\
\text { (SIC2) }\end{array}$ & $0.003(0.25)$ & $0.163(5.97)$ & $5.82 \%$ & 686 \\
\hline $\begin{array}{l}\text { SIC Codes } 5000- \\
5999, \text { and } 7000-8999 \\
\text {-Retail/W holesale and } \\
\text { Service Firms } \\
\text { (SIC } 34 \text { ) }\end{array}$ & $0.070(2.01)$ & $0.146(7.66)$ & $16.42 \%$ & 357 \\
\hline \multicolumn{5}{|l|}{ Empirical P-values } \\
\hline Own $A$ versus $O$ wn $B$ & 0.0448 & 0.1698 & & \\
\hline Own $A$ versus $O$ wn $C$ & 0.3754 & 0.0426 & & \\
\hline Own $B$ versus $O w n C$ & 0.9678 & 0.4098 & & \\
\hline $\mathrm{SIC} 1$ versus $\mathrm{SIC} 2$ & 0.4444 & 0.9738 & & \\
\hline SIC 1 versus $\mathrm{SIC} 3 \& 4$ & 0.7976 & 0.8474 & & \\
\hline SIC2 versus SIC $3 \& 4$ & 0.7968 & 0.4712 & & \\
\hline
\end{tabular}

\section{Conclusions}

Contrary to recent U.S. evidence provided by K aplan and Zingales (1997), and Cleary (1999), the investment-liquidity sensitivity of financially constrained firms is not found to be significantly lower that of unconstrained firms. Surprisingly, partially constrained firms exhibit higher investment-liquidity sensitivity than both constrained and unconstrained firms. 
A n obvious reason for the differences in results from the U.S. studies is the nature of the companies included in the Canadian sample. The present sample contains a lower proportion of manufacturing firms and higher proportion of resource-based companies than the U.S. studies. This is important in light of evidence that resource firms are less sensitive to liquidity than other non-manufacturing firms and than manufacturing firms. Ownership structure is also an important consideration since Canadian companies tend to be closely held relative to U.S. companies, which is the case in this sample where close to 80 percent of the firms had a major shareholder that owned more than 20 percent of its outstanding common shares. The results suggest that the investment outlays of widely held firms are more sensitive to liquidity, than for more closely held firms, which is consistent with previous Canadian evidence.

A side from the industry and ownership structure effects described above, another important difference between this sample and the Cleary (1999) sample, is sample size. This study highlights the importance of this matter by demonstrating how sensitive the results can be to the behavior of a small number of firms. This represents an important observation, since the conclusions of several previous studies are based on small sample results. The implication of these results is that large sample evidence is necessary to obtain insight into the nature of the investment-liquidity relationship.

\section{References}

Altman, Edward I., "Financial Ratios, Discriminant A nalysis and the Prediction of Corporate Bankruptcy," J ournal of Finance, 23 (1968), 589-609.

Cleary, Sean, "The R elationship B etween Firm Investment and Financial Status," J ournal of Finance, 54 (1999), 673-692.

Cummins, J ason G., K evin A. Hassett and R. Glenn Hubbard, "Tax R eforms and Investment: A Cross Country Comparison," J ournal of Public E conomics, (1996), 237-273.

Fazzari, Steven, R. Glenn H ubbard, and B ruce Petersen, "Financing Constraints and Corporate Investment," Brookings Papers on Economic Activity, (1988), 141-195.

Hoshi, Takeo, A nil K. K ashyap, and David Scharfstein, "Corporate Structure Liquidity and Investment: Evidence from J apanese Panel Data," Quarterly J ournal of Economics, 106 (1991), 33-60.

Hubbard, R. Glenn, "Capital M arket Imperfections and Investment," J ournal of E conomic Literature, 36 (1998), 193-225.

K aplan, Steven N ., and L uigi Zingales, "Do Financing Constraints Explain W hy Investment is Correlated with Cash Flow?," Q uarterly J ournal of E conomics, 112 (1997), 169-215.

Schaller, Huntley, "A symmetric Information, L iquidity Constraints, and Canadian Investment," Canadian J ournal of E conomics, 26 (1993), 552-574.

W hited, Toni, "D ebt, Liquidity Constraints, and Corporate Investment: Evidence from Panel Data," J ournal of Finance, 47 (1992), 1425-1460. 